\title{
Genetic divergence among inbred onion lines and correlation with heterosis and combining ability
}

\author{
M.V. Faria ${ }^{1}$, W.L. Zaluski ${ }^{1}$, J. Rosa ${ }^{2}$, E.S. Rossi ${ }^{1}$, J.T.V. Resende ${ }^{1}$, \\ R.F. Kobori ${ }^{3}$, R.L. Santos ${ }^{3}$ and P.R. Da-Silva ${ }^{1,2}$ \\ ${ }^{1}$ Programa de Pós-graduação em Agronomia, Universidade Estadual do \\ Centro-Oeste, Guarapuava, PR, Brasil \\ ${ }^{2}$ Departamento de Ciências Biológicas, Universidade Estadual do Centro- \\ Oeste, Guarapuava, PR, Brasil \\ ${ }^{3}$ Departamento de Pesquisa em Melhoramento de Hortaliças, Estação de \\ Pesquisa e Desenvolvimento Sakata, Bragança Paulista, SP, Brasil
}

Corresponding author: P.R. Da-Silva

E-mail:prsilva@unicentro.br

Genet. Mol. Res. 18 (3): gmr18316

Received March 07, 2019

Accepted July 11, 2019

Published August 27, 2019

DOI http://dx.doi.org/10.4238/gmr18316

\begin{abstract}
Highly heterotic onion hybrids exhibit high yield and superior post-harvest quality. In general, to develop heterotic hybrids, it is first necessary to develop inbred lines with high genetic divergence and good specific combining ability (SCA). We investigated the correlation between SCA, heterosis, and genetic divergence of inbred onion lines. Two groups of inbred onion lines were used as parentals in a partial $(6 \times 5)$ diallel cross. Group I included six $\mathrm{S}_{3}$ male-sterile lines of the "Super Precoce" pedigree (L4827, L4830, L4833, L4835, L4837, and L4839), and group II included five $\mathrm{S}_{2}$ fertile lines of the "Hiper Precoce" pedigree, Granex type with some inter-crosses (L4741, L4742, L4743, L4744, and L4746). Genetic divergence among the parental lines was estimated on the basis of seven morpho-agronomic characters and 10 intersimple sequence repeat (ISSR) markers. Pearson and Spearmann correlations between morphology-based genetic dissimilarity, ISSRbased genetic dissimilarity, heterosis, and SCA were evaluated. Five characters (number of leaves, bulb yield, bulb diameter, soluble
\end{abstract}


solids content, and dry mass) accounted for $82.8 \%$ of the genetic variation present in the genotypes. The greatest genetic dissimilarity, as indicated by both ISSR data (80.4\%) and morpho-agronomic data (92.5\%), was calculated for L4742 and L4744, which demonstrated that these onion inbred lines were genetically divergent. Based on estimates of SCA and heterosis, L4742 was identified as the most promising lineage for developing superior onion hybrids. None of the correlations between SCA, heterosis, and genetic dissimilarity (morpho-agronomic or ISSR) were significant, thereby indicating that genetic dissimilarity cannot be used directly to select parental lines or to predict the best crosses for all characters. However, the genetic dissimilarities estimated using morpho-agronomic characters and ISSR profiles were useful for identifying the best crosses for bulb yield and bulb diameter.

Key words: Allium cepa; Onion hybrid; Onion breeding; ISSR marker

\section{INTRODUCTION}

The use of hybrid seeds by onion producers has increassed because the yield and quality of bulbs are greater than those of open-pollinated cultivars (May et al., 2007; Ragassi et al., 2012). This perspective encourages breeding programs to identify superior lineages that can be used to develop new hybrids, aiming to meet demands in different growing environments (Faria et al., 2012; Quartieiro et al., 2014).

Hybrid vigor (i.e., heterosis) depends on allelic complementarity of loci with nonadditive effects those results from the combination of dissimilar lineages with high productive potential (Cruz et al. 2011). To determine genetic divergence, it is ideal to use multi-varied techniques that allow several characters to be assessed simultaneously. Such techniques should also estimate the genetic distance between parents, thereby helping breeders to target crosses between the most divergent parents and increasing the possibility of developing productive hybrids quickly (Cruz and Carneiro, 2006; Buzar et al., 2007; Santos et al., 2011; Wamser et al., 2012).

Since genetic variation is the basis of plant breeding programs (Morales et al., 2011; Camargo et al., 2013; Morales et al., 2013; Mariano et al., 2019), it is important to understand the genetic variation of core germplasms. In onion, morphological markers have been used to study the genetic divergence of different genotypes (Wamser et al., 2012). However, the use of such markers presents several disadvantages, including the need to evaluate certain variables after the plant reaches the adult phase (Figueiredo et al., 2016). Molecular markers, such as inter-simple sequence repeat (ISSR) markers, can be used instead, especially since they can be applied at any stage of plant development (Rosa et al., 2017; Mariano et al., 2019). Indeed, ISSR markers are highly efficient in detecting genetic polymorphism, are relatively inexpensive, are abundant in the genome, and are repeatable between laboratories (Aguilera et al., 2011; Chagas et al., 2015). Furthermore, when morphological and molecular markers are used together, the resulting data are generally highly reliable. 
Few studies have estimated the genetic divergence of onion genotypes to promote productive breeding (Buzar et al., 2007; Ragassi et al., 2012; Wamser et al., 2012). We evaluated the correlation between genetic dissimilarity of inbred onion lines and the SCAs determined by diallelic crosses.

\section{MATERIAL AND METHODS}

\section{Inbred onion lines and crosses}

Two groups of inbred onion lines from the Sakata Seed Sudamerica Ltda. germplasm bank were used as parental lines in a partial 6x5 diallel cross (Table 1). Group I included six $\mathrm{S}_{3}$ male-sterile inbred onion lines of the "Super Precoce" pedigree, which were selected on the basis of bulb color and shape and adaptation to the tropical and subtropical conditions of Brazil (L4827, L4830, L4833, L4835, L4837, and L4839). Group II included five $\mathrm{S}_{2}$ fertile inbred onion lines of the "Hiper Precoce" pedigree, Granex type with some inter-crosses (L4741, L4742, L4743, L4744, and L4746). These crosses resulted in 30 experimental hybrids (Table 1), which were evaluated according to Griffing (1956), as adapted by Cruz and Carneiro (2006).

The experiment was carried out in an experimental field (Midwest State University of Paraná, Guarapuava, PR, Brazil) in a trial design of complete blocks with treatments assigned at random and with two replications per treatment. Each plot encompassed $1.2 \mathrm{~m}^{2}(1.2 \mathrm{~m}$ width $\times 1.0 \mathrm{~m}$ length $)$ and contained 80 plants that were distributed in eight lines, with $0.15 \mathrm{~m}$ between lines, $0.10 \mathrm{~m}$ between plants, and a population equivalent to 660,000 plants $\mathrm{ha}^{-1}$.

Table 1. Experimental inbred onion lines and corresponding onion hybrids that were evaluated.

\begin{tabular}{llllll}
\hline Q/ & L4741 & L4742 & L4743 & L4744 & L4746 \\
\hline L4827 & HB4471 & HB4477 & HB4483 & HB4489 & HB4495 \\
L4830 & HB4472 & HB4478 & HB4484 & HB4490 & HB4496 \\
L4833 & HB4473 & HB4479 & HB4485 & HB4491 & HB4497 \\
L4835 & HB4474 & HB4480 & HB4486 & HB4492 & HB4498 \\
L4837 & HB4475 & HB4481 & HB4487 & HB4493 & HB4499 \\
L4839 & HB4476 & HB4482 & HB4488 & HB4494 & HB4500 \\
\hline
\end{tabular}

\section{Morpho-agronomic analysis}

Seven quantitative traits were selected based on the multicollinearity diagnosis for the study of genetic divergence: number of leaves per plant (NL), bulb diameter (BD), bulb yield (BY), bulb firmness (F), pyruvic acid content (PA), soluble solids content (SS), and percentage of dry mass (DM).

The genetic divergence among the inbred onion lines, based on the morphoagronomic characters, was determined using cluster analysis, with the Modified Tocher optimization method, as described by Cruz et al. (2012). First, the Mahalanobis generalized distance $\left(\mathrm{D}^{2}\right)$, which is a measure of inbred onion lines dissimilarity, was 
estimated. Then, using the resulting set of distance values, the inbred onion lines were grouped so that the mean inter-group distance was lower than any other inter-group distances. The highest mean inter-group distance value was established as the highest $\mathrm{D}^{2}$ value, obtained in the set of shorter distances involving each inbred online line.

In addition, the divergence of the inbred onion lines was assessed using scatter plots, as described by Cruz et al. (2012), and the relative importance of each characters was estimated for studying genetic divergence, according to Singh (1981). Pearson and Spearmann correlations were calculated between $D_{i i i^{2}}^{2}$, genetic dissimilarity by ISSR, heterosis, SCA, and mean BY, BD, and PA values.

\section{Molecular analyses}

DNA for each inbred onion line was extracted from the internal cataphylls of corresponding bulbs, according to Doyle and Doyle (1987). After extraction, the DNA was dried, re-suspended in ultra-pure water, and stored at $-20^{\circ} \mathrm{C}$ until use. Each DNA sample was quantified by electrophoresis, using $0.9 \%$ agarose gel stained with ethidium bromide and a standard of known amounts of $\lambda$ phage DNA $(50,100,200$, and $400 \mathrm{ng})$.

Polymerase chain reaction (PCR) was then performed using 10 ISSR primers, which were developed by the University of British Columbia, Vancouver, Canada. Each 12.5- $\mu \mathrm{L}$ PCR reaction contained $20 \mathrm{ng}$ DNA, $0.2 \mu \mathrm{M}$ primer, $200 \mu \mathrm{M}$ of each dNTP, $1.5 \mathrm{mM} \mathrm{MgCl}_{2}, 1 \mathrm{U}$ Taq DNA polymerase, and 1X PCR buffer and was amplified using the following conditions: an initial denaturing step at $94^{\circ} \mathrm{C}$ for $5 \mathrm{~min}$; followed by 35 cycles of $94^{\circ} \mathrm{C}$ for $45 \mathrm{~s}$, annealing temperature of primer for $45 \mathrm{~s}$, and $72^{\circ} \mathrm{C}$ for $90 \mathrm{~s}$; and a final extension step of $72^{\circ} \mathrm{C}$ for $7 \mathrm{~min}$.

The amplification products were visualized by electrophoresis for $3 \mathrm{~h}$ at $110 \mathrm{~V}$ in $1.8 \%$ agarose gel stained with ethidium bromide $\left(0.5 \mu \mathrm{g} . \mathrm{mL}^{-1}\right)$. The gels were visualized using UV light and photo-documented with a digital system. The sizes of the amplified fragments were determined by comparison to a 123 bp DNA Ladder.

Only bands with good resolution were considered for genotyping. Each inbred onion line was genotyped according to the presence (1) and absence (0) of bands and recorded in a binary matrix. The percentage polymorphism of each ISSR primer was calculated by dividing the total number of polymorphic fragments by the total number of amplified fragments.

The genetic dissimilarities of the inbred onion lines were calculated using the Jaccard coefficient, and a dendrogram was generated using the UPGMA (Unweighted Pair Group Method with Arithmetic Mean) method. The reliability of the dendrogram nodes was tested using bootstrap methodology, with 1000 resamplings. The cut-off point of the dendrogram was calculated using the following expression: $\theta_{k}=\bar{\alpha}+K \hat{\sigma}_{\alpha}$, where $\theta_{k}$ represents the cut-off point; $\bar{\alpha}$ and $\hat{\sigma}_{\alpha}$ represent the mean and standard deviation, respectively, of the distances corresponding to stage $\mathrm{j}$; and $\mathrm{K}$ is a constant (1.25; Mojema, 1977; Cruz et al., 2011). The Cophenetic correlation coefficient (CCC) was calculated in order to test the efficiency of the cluster method. The analyses were performed using the software GENES (Cruz, 2013). 


\section{RESULTS AND DISCUSSION}

\section{Morpho-agronomic markers}

Because phenotypic characters that are used to study genetic divergence should not be correlated with each other and should vary among genotypes, only quantitative characters that were significantly affected by inbred onion line genotype and that exhibited weak multicollinearity were selected. Multicollinearity is defined as the level at which any effect of a variable can be predicted or explained by other variables; this is a basic assumption of the cluster analysis and can lead to improper analyses when not applied (Cargnelutti Filho et al., 2009). The multicollinearity value observed for the seven selected characters was relatively low (72.66), thereby validating the subsequent cluster analysis (Cruz and Carneiro, 2006).

The relative contributions of the morpho-agronomic characters to the genetic divergence among the inbred onion lines are shown in Table 2.

Table 2. Estimated relative contribution of morpho-agronomic characters to the genetic divergence of 11 parental inbred onion lines.

\begin{tabular}{lllllc}
\hline Character & Contribution & Accumulated & Character & Contribution & Accumulated \\
\hline BY & $11.86 \%$ & $11.86 \%$ & SS & $15.97 \%$ & $78.38 \%$ \\
BD & $27.86 \%$ & $39.72 \%$ & DM & $12.39 \%$ & $90.77 \%$ \\
NL & $14.76 \%$ & $54.48 \%$ & PA & $-23 \%$ & $100.0 \%$ \\
F & $7.93 \%$ & $62.41 \%$ & - & - & - \\
\hline
\end{tabular}

BY: bulb yield; BD: bulb diameter; NL: number of leaves; F: bulb firmness; SS: soluble solids content; DM: dry mass; PA: pyruvic acid content.

Bulb diameter (BD) had the greatest contribution (27.86\%), indicating that this character would be useful for selecting genotypes. However, five characters (BY, BD, $\mathrm{NL}, \mathrm{SS}$, and DM) were needed to reach an accumulated relative contribution above $80 \%$, in this case $82.8 \%$, highlighting the usefulness of these characters for studying the genetic divergence of onion genotypes. Nonetheless, it is important to note that bulb firmness (F) and pyruvic acid content (PA) were reported by Singh (1981) as characters that contributed the least to the study of genetic divergence (7.93 and $9.23 \%$, respectively) (Table 2).

The mean Mahanalobis generalized distance $\left(\mathrm{D}^{2}\right)$ was $31.99 \%$, and the smallest genetic distance was between L4833 and L4827 (3.7\%; Table 3), whereas the greatest was between L4744 and L4742 (92.5\%; Table 3). Buzar et al. (2007) and Wamser et al. (2012) analyzed the genetic diversity of onion germplasm using morpho-agronomic characters; they obtained similar results and concluded that their genotypes had a high level of genetic diversity. Similarly, based on the results obtained by analyzing morphoagronomic characters, the onion lineages that we evaluated should be classified as exhibiting high genetic variation. 
Table 3. Genetic divergence of inbred onion lines. Mahalanobis generalized distance $\left({ }_{D_{i i}^{2}}^{2}\right.$; above the diagonal) and genetic divergence (\%) estimated using the Jaccard coefficient from ISSR data (below the diagonal).

\begin{tabular}{|c|c|c|c|c|c|c|c|c|c|c|c|}
\hline & L4741 & L4742 & L4743 & L4744 & L4746 & L4827 & L4830 & L4833 & L4835 & L4837 & L4839 \\
\hline$\overline{741}$ & 0 & 65.5 & 38.1 & 51.9 & 44.2 & 49.5 & 11.6 & 48.7 & 58.1 & 68.2 & 20.1 \\
\hline L4742 & 75.0 & 0 & 44.3 & 92.5 & 39.6 & 29.8 & 53.9 & 29.2 & 17.4 & 26.7 & 61.2 \\
\hline L4743 & 47.7 & 60.9 & 0 & 21.4 & 7.4 & 20.5 & 15.2 & 15.7 & 21.6 & 19.7 & 9.9 \\
\hline L4744 & 47.4 & 80.4 & 51.1 & 0 & 47.2 & 70.7 & 44.9 & 67.2 & 73.4 & 75.4 & 15.8 \\
\hline L4746 & 67.4 & 58.5 & 47.8 & 70.2 & 0 & 18.8 & 15.7 & 7.92 & 15.1 & 18.5 & 23.4 \\
\hline L4827 & 52.6 & 73.8 & 70.0 & 56.4 & 65.9 & 0 & 20.2 & 3.7 & 7.9 & 5.5 & 27.8 \\
\hline L4830 & 60.5 & 64.3 & 50.0 & 69.6 & 38.5 & 55.0 & 0 & 17.6 & 28.8 & 32.7 & 10.1 \\
\hline L4833 & 58.3 & 58.7 & 60.0 & 61.2 & 45.7 & 39.0 & 44.4 & 0 & 7.6 & 7.2 & 27.9 \\
\hline L4835 & 60.0 & 60.5 & 58.8 & 60.0 & 50.0 & 35.1 & 37.5 & 26.2 & 0 & 7.6 & 37.9 \\
\hline L4837 & 65.2 & 48.7 & 68.5 & 73.5 & 55.6 & 46.2 & 51.2 & 28.6 & 32.5 & 0 & 40.3 \\
\hline L4839 & 59.5 & 56.4 & 58.3 & 68.9 & 45.0 & 53.8 & 35.1 & 43.2 & 40.0 & 42.5 & 0 \\
\hline
\end{tabular}

The clustering of genotypes based on morpho-agronomic characters, using Mahalanobis generalized distances, isolated inbred onion lines L4742 and L4744 and distributed the remaining genotypes among two groups: group I, which included six inbred onion lines, and group II, which included three (Figure 1).

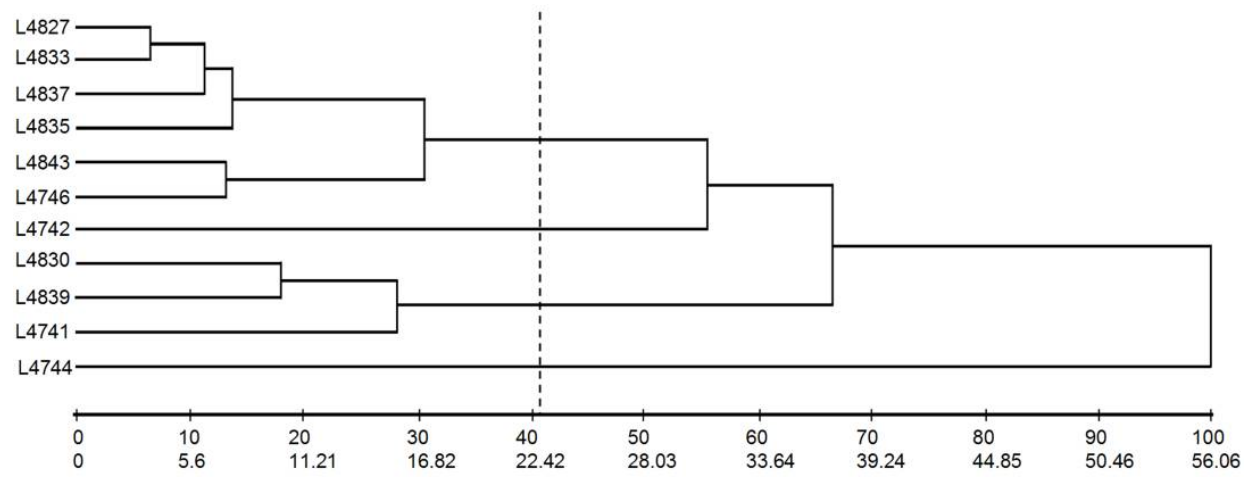

Figure 1. Dendrogram with the Mahalanobis generalized distances among inbred onion lines obtained using seven quantitative morpho-agronomic characters.

The use of morpho-agronomic characters in estimating dissimilarity has effectively contributed to the breeding of other crops (Barili et al., 2011), and the most frequently employed method for estimating dissimilarity using morphological variables is the Mahalanobis generalized distance $\left(\mathrm{D}^{2}\right)$. This method allows the integration of several types of information for a set of characters and the quantification of genetic divergence to select divergent parents in breeding programs (Fonseca et al., 2006). These results indicate that the combination of morpho-agronomic characters and use of Mahalanobis generalized distance is also efficient for identifying divergent lines of onion. 


\section{Molecular markers}

Seven of the 10 ISSR primers exhibited successful amplification and sufficient levels of polymorphism (Table 4), whereas primers UBC-827, UBC-855, and UBC-866 were not used in the analyses, owing to either poor amplification or monomorphic status.

The seven selected ISSR primers amplified 85 bands, of which 58 were polymorphic (Table 4), and each primer amplified a mean of 12.14 bands, of which a mean of 8.28 were polymorphic (Table 4). The mean rate of polymorphism was $69.71 \%$, and the size of the amplified bands ranged from 185 to $1500 \mathrm{bp}$ (Table 4). The most polymorphic primers were 808,848 , and 857 , for which 78,86 , and $89 \%$ of the amplified bands were polymorphic, respectively (Table 4 ).

Table 4. Inter-simple sequence repeat (ISSR) primers used to assess the genetic divergence of onion genotypes. AT: annealing temperature; AP: amplification product; TNB: total number of bands; NPB: number of polymorphic bands; P: percentage of polymorphism; IBS: interval of band size.

\begin{tabular}{llllllll}
\hline Primer & Sequence 5'-3' & AT ${ }^{\circ} \mathbf{C}$ & AP & TNB & NPB & P (\%) & IBS (bp) \\
\hline UBC-807 & (AG)8T & 52 & yes & 13 & 6 & 46 & $185-984$ \\
UBC-808 & (AG)8C & 50 & yes & 9 & 7 & 78 & $246-738$ \\
UBC-810 & (GA) T $_{\text {T }}$ & 52 & yes & 11 & 7 & 64 & $231-738$ \\
UBC-827 & (AC)8G & 53 & no & - & - & - & - \\
UBC-834 & (AG)8CTT & 52 & yes & 16 & 9 & 56 & $211-1353$ \\
UBC-836 & (AG)8YA & 53 & yes & 13 & 9 & 69 & $246-1500$ \\
UBC-848 & (CA)8AGG & 55 & yes & 14 & 12 & 86 & $231-881$ \\
UBC-855 & (AC)8CTT & 55 & no & - & - & - & - \\
UBC-857 & (AC)8CTG & 54 & yes & 9 & 8 & 89 & $184-738$ \\
UBC-866 & (CTC)5 & 55 & no & - & - & - & - \\
\hline Total & - & - & & 85 & 58 & - & - \\
\hline Mean & & & & & & 8.28 & 69.71 \\
\hline
\end{tabular}

ISSR markers have been widely used to detect polymorphism in onions. However, rates of polymorphism vary. Indeed, previous studies have reported rates of $79.48 \%$ (Qijiang et al., 2007) and 80\% (Wamser et al., 2014), whereas the rate of polymorphism identified in our study was $69.71 \%$, which is considered high, since the inbred onion lines assessed here possess intermediate levels of homozygosis and originated from two distinct germplasm groups.

The mean genetic dissimilarity between the inbred onion lines, as estimated by the Jaccard coefficient using ISSR data, was $49.5 \%$, with values ranging from 26.2 (between L4833 and L4835) to 80.4\% (between L4742 and L4744; Table 3), which suggested the occurrence of genetic variation among the inbred onion lines. The highest genetic dissimilarity (between L4742 and L4744) coincides with the results obtained using Mahalanobis generalized distance (Table 3). Interestingly, both the molecular and morphoagronomic analyses indicated that these inbred onion lines (L4742 and L4744) were genetically divergent, even though they belonged to the same group of genitors, formed by the $\mathrm{S}_{2}$ lineage fertile male of the "Hyper Precoce" pedigree (granex type, with some crosses).

The coefficient of cophenetic correlation (r) obtained based on the Jaccard genetic dissimilarity was 0.84 , demonstrating adequate adjustment between the graphic 
representation of the distances and the original matrix (Figure 2). Such information is of major importance to breeding strategies, since, in general, the most similar genotypes are not used in crosses, because low heterotic effects are expected.

The cut-off point calculated according to Mojema (1977) was 0.46, which separated the dendrogram into two groups (Figure 2). Group I was formed by three inbred onion lines, and group II was formed by six. The least genetic dissimilarity was observed between L4833 and L4835 and between L4833 and L4837 (Table 2). Crosses among each other were not performed, as they formed the same group of progenitors. Of the crosses that were performed, the lowest genetic dissimilarity was that of L4746 and L4830 (38.5\%; Table 3). Hybrid HB4496 exhibited negative values of heterosis and SCA in six of the 10 variables analyzed, which demonstrated low estimates of heterosis for bulb yield $\left(\mathrm{H}=2.9\right.$ t.ha $\left.^{-1}\right)$ and negative CEC $\left(\mathrm{s}_{\mathrm{ij}}=-0.55 \mathrm{t}^{\mathrm{h}} \mathrm{h}^{-1}\right)$, thereby demonstrating that cross inbred onion lines with low genetic dissimilarity is not favorable to the development of good hybrids.

In the dendrograms, L4742 was isolated from the other lines, along with lineage L4744, and yielded the highest value of dissimilarity (80.4\%; Figure 2). However, because the experiment involved a partial diallel cross, in which the parental lines are separated into two groups, the cross between these inbred onion lines (L4742 and L4744) was not performed, since they belonged to the same group. According to Maluf et al. (1983), parental lines that yield higher estimates of genetic dissimilarity are those which, when crossed, are more likely to produce highly heterotic individuals for a variety of agronomic characters.

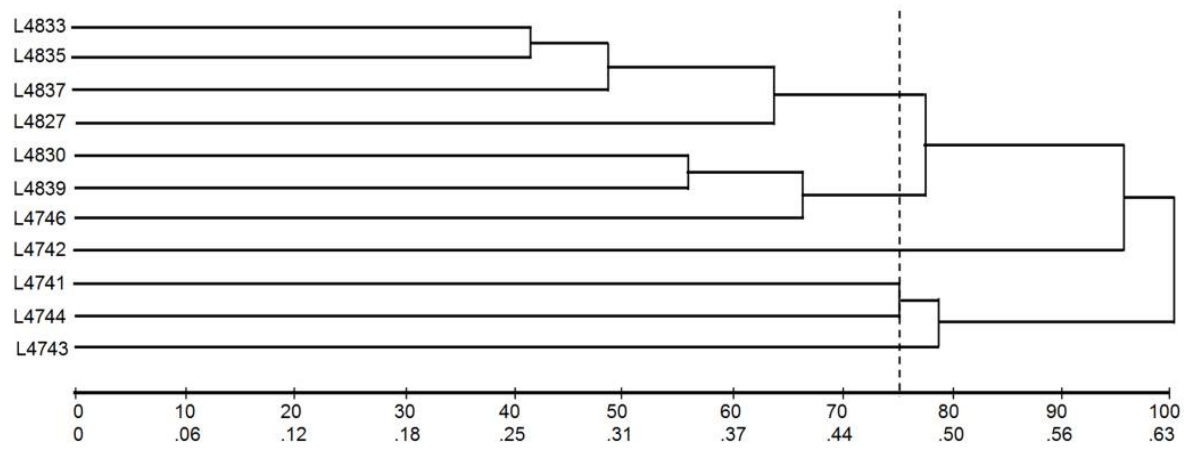

Figure 2. Genetic dissimilarity of 11 inbred onion lines. Distances were calculated using data from 58 intersimple sequence repeat markers.

Because molecular markers, such as ISSR markers, are often spread throughout plant genomes, individuals with higher genetic dissimilarity are not always associated with high estimates of SCA and heterosis, since markers may be located in genomic regions that are relatively unimportant in terms of agronomic traits (Souza Junior, 2001).

Estimates of Pearson and Spearmann correlations between ${ }_{D_{i i}^{2}}^{2}$, heterosis, SCA, and mean BY and PA values were not significant (Table 5), thereby demonstrating that only $D_{i i^{\prime}}^{2}$ estimates cannot be used directly to develop high-yielding and heterotic hybrids. This absence of correlation could be related to the fact that BY is a quantitative character, which can exhibit two-dimensional dominance, in which loci may exert opposing effects, since genetic divergence does not guarantee heterotic gains, because heterosis depends on 
dominance and epistatic interactions, not only on differences in allele frequencies (Oliboni et al., 2013). On the other hand, for BD, significant $(\mathrm{P}<0.05)$ correlations of Pearson and Spearmann coefficients were noted between $D_{i i^{\prime}}^{2}$ and the phenotypic mean observed in their respective hybrids (Table 5), which suggests that the hybrids with the greatest $\mathrm{BD}$ mean originated from the crossing of genetically divergent progenitors. The same level of significance was observed for the correlation between $D_{i i^{\prime}}^{2}$ and heterosis, which is indicative of $D_{i i^{\prime}}^{2}$ as a tool for targeting the most promising crosses for developing onion hybrids with large BD.

Table 5. Correlations between genetic distance, heterosis, specific combining ability, and morphoagronomic characters in 44 hybrid offspring from a partial diallel cross of inbred onion lines.

Mahalanobis generalized distance; $\mathrm{H}$ : heterosis; $\hat{\mathrm{S}}_{\mathrm{ij}}$ : specific combining ability; BY: bulb yield; BD: bulb diameter; PA: pyruvic acid content.

\begin{tabular}{|c|c|c|c|c|c|c|c|c|c|}
\hline \multirow{2}{*}{ Variable } & & \multicolumn{4}{|c|}{ Pearson } & \multicolumn{4}{|c|}{ Spearmann } \\
\hline & & $D_{i i^{\prime}}^{2}$ & Jaccard & $\mathbf{H}$ & $\hat{\mathbf{S}}_{\mathrm{ij}}$ & $D_{i i^{\prime}}^{2}$ & Jaccard & $\mathbf{H}$ & $\hat{\mathbf{S}}_{\mathrm{ij}}$ \\
\hline \multirow{5}{*}{ BY } & Jaccard & -0.23 & & & & -0.28 & & & \\
\hline & $\mathrm{H}$ & 0.18 & 0.26 & & & 0.24 & 0.30 & & \\
\hline & $\hat{\mathrm{S}}_{\mathrm{ij}}$ & 0.21 & 0.27 & $0.90^{* *}$ & & -0.14 & 0.27 & $0.87 * *$ & \\
\hline & Mean & -0.26 & 0.15 & $0.81 * *$ & $0.72 * *$ & 0.38 & 0.09 & $0.84 * *$ & $0.75^{* *}$ \\
\hline & $\mathrm{H}$ & $0.44^{*}$ & 0.33 & & & $-0.45^{*}$ & 0.33 & & \\
\hline \multirow[t]{3}{*}{$\mathrm{BD}$} & $\hat{\mathrm{S}}_{\mathrm{ij}}$ & 0.14 & 0.33 & $0.65^{* *}$ & & 0.30 & 0.42 & $0.67 * *$ & \\
\hline & Mean & $0.38 *$ & 0.21 & $0.82 * *$ & $0.62 * *$ & $-0.48^{*}$ & 0.19 & $0.86^{* *} *$ & $0.66^{* *}$ \\
\hline & $\mathrm{H}$ & 0.16 & $0.41 *$ & & & 0.19 & - *0.42* & & \\
\hline \multirow[t]{2}{*}{ PA } & $\hat{\mathrm{S}}_{\mathrm{ij}}$ & -0.10 & 0.15 & $0.64^{*}$ & & 0.30 & 0.42 & $0.63 *$ & \\
\hline & Mean & 0.17 & -0.30 & $0.80 * *$ & $0.85^{* *}$ & 0.21 & -0.28 & $0.83 * *$ & 0.66 \\
\hline
\end{tabular}

Positive and significant correlation coefficients $(\mathrm{P}<0.01)$ were observed, for both the Pearson and Spearmann analyses, between means of BY, BD, PA and heterosis, between means of $\mathrm{BY}, \mathrm{BD}$, and $\mathrm{PA}$ and $\mathrm{SCA}$, and between heterosis and SCA. These results indicated that hybrids with higher phenotypic values for variables BY, BD and PA were obtained from hybrid combinations of high heterosis and SCA (Table 5). Heterosis and SCA are intimately related since both depend on genes with non-additive effects (Cruz et al., 2012), and higher SCA and heterosis have been reported for bulb yield (Havey and Randle, 1996).

The usefulness of specific morpho-agronomic characters for studying genetic divergence can also be assessed before the magnitude of the weighting coefficient from the last canonical variables; the characters with higher magnitudes must be excluded from future studies (Cruz et al., 2011). In the present study, considering the weighting coefficients of the last two canonical variables, dry mass $\left(\mathrm{DM} ; \mathrm{CV}_{7}\right.$ and weighting coefficient 0.561 ) was identified as a variable that must be excluded from future studies (Table 6). It is also worth noting that according to Singh (1981) method, the bulb firmness $(\mathrm{F})$ was the least valuable variable for studying genetic divergence (Table 2) and that it should be excluded from future studies of genetic divergence in onion. 
Table 6. Auto-values $\left(\lambda_{\mathrm{i}}\right)$ corresponding to the variation percentages explained by canonical variables $\left(\mathrm{CV}_{\mathrm{i}}\right)$ and relative importance of seven agronomic quantitative and qualitative characters assessed in 10 inbred onion lines.

\begin{tabular}{|c|c|c|c|c|c|c|c|c|c|}
\hline \multirow{2}{*}{$C V_{i}$} & \multicolumn{2}{|c|}{ auto-values } & \multicolumn{7}{|c|}{ Relative importance of the characters } \\
\hline & $\lambda_{\mathrm{i}}$ & $\%$ acum & BY & BD & NL & $\mathbf{F}$ & SS & DM & $\mathbf{P A}$ \\
\hline $\mathrm{CV}_{1}$ & 8.68 & 54.28 & 1.318 & -0.771 & -1.354 & -0.400 & 0.720 & 0.954 & 1.003 \\
\hline $\mathrm{CV}_{2}$ & 3.37 & 75.33 & 1.028 & 0.684 & -1.129 & 0.335 & 0.398 & -0.018 & 0.399 \\
\hline $\mathrm{CV}_{3}$ & 2.38 & 90.22 & -0.329 & 0.252 & 0.910 & -0.638 & 0.539 & 0.198 & -0.477 \\
\hline $\mathrm{CV}_{4}$ & 0.98 & 96.35 & 0.068 & 0.038 & -0.394 & -0.746 & -0.494 & 0.490 & -0.495 \\
\hline $\mathrm{CV}_{5}$ & 0.32 & 98.37 & -0.524 & 0.371 & 0.098 & -0.399 & 0.032 & 0.301 & 0.733 \\
\hline $\mathrm{CV}_{6}$ & 0.25 & 99.96 & -0.850 & 0.292 & 0.000 & 0.086 & 0.280 & 0.564 & -0.071 \\
\hline $\mathrm{CV}_{7}$ & 0.01 & 100.00 & 0.026 & -0.031 & 0.324 & 0.336 & -0.395 & 0.561 & 0.167 \\
\hline
\end{tabular}

Furthermore, lineage L4742 exhibited characters that are favorable to onion breeding, especially if breeding programs are focused on developing productive and highly heterotic hybrids. The two hybrids that showed the highest SCA and heterosis estimates were derived from lineage L4742, further demonstrating its usefulness for developing superior hybrids.

\section{Comparison of morpho-agronomic and molecular markers}

Dissimilarity coefficients can be used to guide the selection of adequate parental lines for developing highly heterotic hybrids (Morales et al., 2011). The Pearson and Spearmann correlation coefficients for genetic dissimilarity (Jaccard) of the inbred onion lines and the mean morpho-agronomic values of their respective hybrids were not significant for either BY or BD (Table 5). However, the greatest BY and BD values originated from the combination of more divergent inbred onion lines, as indicated by the ISSR data. These results highlight ISSR markers as important tools in the prediction of good onion hybrids, at least in regards to BY and BD.

The estimation of genetic diversity in onion germplasm (Liu and Wu, 2013; Jin et al., 2013) and molecular characterization of onion using ISSR markers (Nikhil et al., 2015) are related. However, few studies have correlated the values of genetic dissimilarity obtained using ISSR markers with heterosis, SCA, or morpho-agronomic characters (phenotypic means), and even those studies have only calculated genetic distance in order to characterize germplasm. Figueiredo et al. (2016), for example, assessed 10 tomato inbred lines using 12 ISSR markers and correlated the genetic diversity with heterosis, SCA, and morphologic diversity. The authors demonstrated, through correlation, that genetic dissimilarity estimated using ISSR data can facilitate the selection of inbred lines for breeding superior hybrids. Together, the results of this study and those of the present study support the conclusion that ISSR markers can help breeders plan crosses to develop superior onion hybrids.

\section{CONCLUSIONS}

No significant correlations were observed between Mahalanobis distance, the Jaccard coefficient, heterosis, SCA $\left(\hat{\mathrm{S}}_{\mathrm{ij}}\right)$, or the phenotypic means of bulb yield, bulb 
diameter, or pyruvic acid content. However, the genetic dissimilarity estimates for both the agronomic and molecular markers were efficient in identifying the best crosses for generating hybrids with greater bulb yield and diameter. The L4742 lineage exhibited the greatest divergence, according to both the molecular and morpho-agronomic markers and was useful for increasing both the SCA and heterosis of resulting hybrids.

\section{ACKNOWLEDGMENTS}

We are grateful to Sakata Seed Sudamerica Ltda for financial support and for supplying genetic material. This study was financed in part by the Coordenação de Aperfeiçoamento de Pessoal de Nível Superior - Brasil (CAPES) - Finance Code 001.

\section{CONFLICTS OF INTEREST}

The authors declare no conflict of interest.

\section{REFERENCES}

Aguilera JG, Pessoni LA, Rodrigues GB, Elsayed AY, et al. (2011). Genetic variability by ISSR markers in tomato (Solanum lycopersicon Mill.). Rev. Bras. Ciênc. Agrár. 6: 243-252.

Barili LD, Vale NM, Arruda B, Toaldo D, et al. (2011). Escolha de genitores contrastantes para compor o bloco de cruzamentos de genótipos de feijão. Rev. Bras. Agrociênc. 17: 303-310.

Buzar AGR, Oliveira VR and Boiteux LS (2007). Estimativa da diversidade genética de germoplasma de cebola via descritores morfológicos, agronômicos e bioquímicos. Hortic. Bras. 25: 527-532.

Camargo LK, Mogor AF, Resende JT and Da-Silva PR (2013). Establishment and molecular characterization of a sweet potato germplasm bank of the highlands of Parana State, Brazil. Genet. Mol. Res. 12: 5574-5588.

Cargnelutti Filho A, Storck L and Ribeiro ND (2009). Agrupamento de cultivares de feijão na ausência e presença de multicolinearidade. Ciênc. Rural. 39: 2409-2418.

Chagas KPT, Sousa RF, Fajardo CG and Vieira FA (2015). A. Seleção de marcadores ISSR e diversidade genética em uma população de Elaeis guineenses. Rev. Bras. Ciênc. Agrár 10: 147-152.

Cruz CD (2013). GENES - a software package for analysis in experimental statistics and quantitative genetics. Acta Scient. Agron. 35: 271-276.

Cruz CD and Carneiro PCS (2006). Modelos biométricos aplicados ao melhoramento genético. $2^{\mathrm{a}}$ ed. Editora UFV, Viçosa.

Cruz CD, Ferreira FM and Pessoni LA (2011). Biometria aplicada ao estudo da diversidade genética. $1^{\text {a }}$ ed. Editora Suprema, Visconde de Rio Branco.

Cruz CD, Regazzi AJ and Carneiro PCS (2012). Modelos biométricos aplicados ao melhoramento genético. Editora UFV, Viçosa.

Doyle JJ and Doyle JL (1987). Isolation of plant DNA from fresh tissue. Focus. 12: 13-15.

Faria MV, Morales RGF, Resende JTV, Zanin DS, et al. (2012). Desempenho agronômico e heterose de genótipos de cebola. Hortic. Bras. 30: 220-225.

Figueiredo AST, Resende JTV, Faria MV, Da-Silva PR, et al. (2016). Prediction of industrial tomato hybrids from agronomic traits and ISSR molecular markers. Genet. Mol. Res. 15: gmr15027981.

Fonseca AFA, Sediyama T, Cruz CD, Sakayama NS, et al. (2006). Divergência genética em café conilon. Pesq. Agrop. Bras. 41: 599-605.

Griffing B (1956). Concept of general and specific combining ability in relation to diallel crossing systems. Aust. J. Biol. Sci. 9: 463-493.

Havey M and Randle W (1996). Combining abilities of open-pollinated long-day onion populations. J. Amer. Soc. Hort. Sci. 121: 604-608.

Jin X, Zhou XG, Liu SW and Wu FZ (2013). ISSR Markers of 48 tillering onion (Allium cepa var. aggregatum) germplasms genetic diversity and analysis of their agronomic traits. China Vegetables. 1(2): 27-34.

Liu S and Wu F (2013). Phenotype and genetic diversity in Chinese onion cultivars from three provinces of northeast China. Biochem. Systemat. Ecol. 49: 77-86.

Maluf WR, Ferreira PE and Miranda JEC (1983). Genetic divergence in tomatoes and its relationship with heterosis for yield in hybrids. Rev. Bras. Genet. 6: 453-460.

Genetics and Molecular Research 18 (3): gmr18316

OFUNPEC-RP www.funpecrp.com.br 
Mariano LC, Zchonski FL, da Silva CM and Da-Silva PR (2019). Genetic variability in a Brazilian apple germplasm collection with low chilling requirements. Peer J. 6: e6265.

May A, Cecílio Filho AB, Porto DRQ, Vargas PF, et al. (2007). Produtividade de híbridos de cebola em função da população de plantas e da fertilização nitrogenada e potássica. Hortic. Bras. 25: 53-59.

Mojema R (1977). Hierarquial grouping methods and stopping rules: an evaluation. Computer J. 20: 359-363.

Morales RGF, Resende JTV, Faria MV, Andrade MC, et al. (2011). Genetic similarity among strawberry assessed by RAPD and ISSR markers. Sci. Agric. 68: 665-670.

Morales RGF, Resende JTV, Resende FV, Delatorre CA, et al. (2013). Genetic divergence among Brazilian garlic cultivars based on morphological characters and AFLP markers. Genet. Mol. Res. 12: 270-281.

Nikhill BSK, Jadhay AS and Kute NS (2015). Molecular characterization of onion (Allium cepa L.) using ISSR markers. Ecol. Environ. Internat. 21: 199-203.

Oliboni R, Faria MV, Neumann, M, Resende JTV, et al. (2013). Diallelic analysis in assessing the potential of maize hybrids to generate base-populations for obtaining lines. Semina: Ciênc. Agrár. 34: 7-18.

Qijiang X, Chengri C and Tiejin J (2007). Genetic diversity analysis of onion (Allium cepa L.) germplasm by ISSR markers. Chin. Agric. Sci Bulletin 32: 54-66.

Quartiero A, Faria MV, Resende JTV, Figueiredo AST, et al. (2014). Desempenho agronômico, heterose e estabilidade fenotípica de genótipos de cebola. Hortic. Bras. 32: 259-266.

Ragassi CF, Santos MDM, Fonseca MEN, Oliveira VR, et al. (2012). Genotipagem de polimorfismos associados com sistemas de macho-esterilidade em acessos de cebola adaptados ao Brasil. Hortic. Bras. 30: 409-414.

Rosa JD, Weber GG, Cardoso R, Górski F, et al. (2017). Variability and population genetic structure in Achyrocline flaccida (Weinm.) DC., a species with high value in folk medicine in South America. PLoS One. 12: 0183533.

Santos CAF, Oliveira VR, Rodrigues MA, Ribeiro HLC, et al. (2011). Similaridade genética entre cultivares de cebola de diferentes tipos e origens, baseada em marcadores AFLP. Hortic. Bras. 29: 32-37.

Singh (1981). The relative importance of characters affecting genetic divergence. Ind. J. Genet. Plant Breed. 41: 237245.

Souza Júnior CL (2001) Melhoramento de espécies alógamas. In: Recursos genéticos e Melhoramento - Plantas (Nass LL, Valois ACC, Melo IS, Valadares MC, Eds.). Fundação MT, Rondonópolis.

Wamser GH, Arruda B, Stinghen JC, Rozzetto DS, et al. (2012). Caracterização e estimativa da variabilidade genética de genótipos de cebola. Hortic. Bras. 30: 327-332.

Wamser GH, Coimbra JLM, Guidalin AF, Lannes SD, et al. (2014). Characterization of onion genotypes using RAPD molecular markers. Rev. Ciênc. Agron. 45: 573-580. 